Chmurski, Mateusz. "From Autobiography to Fiction, or Translating Géza Csáth's Diary from Hungarian to French and to Polish." Hungarian Cultural Studies. e-Journal of the American Hungarian Educators Association, Volume 6 (2013): http://ahea.pitt.edu DOI: 10.5195/ahea.2013.113

\title{
From Autobiography to Fiction, or Translating Géza Csáth's Diary from Hungarian to French and to Polish
}

\section{Mateusz Chmurski}

\begin{abstract}
The aim of this paper is to analyze the complex relation between autobiography and fiction in the work of the Hungarian psychiatrist, writer and music critic Géza Csáth (the pen name of József Brenner [1887-1919]), in particular his 1912-1913 diary, usually called the morfinista napló [diary of a morphine addict], by comparing its Polish and French translations as a means of highlighting alternative interpretations of the diary itself. Because the choices that were made when translating such fragmented texts already imply more or less developed interpretations of them, variations between them can be examined side by side in order to reveal sometimes widely diverging understandings of the diaries' meaning, purpose and general structure. The decision-making that led to the translators' choices is not only examined here case by case, but also in the context of an assumed overarching reading of these diaries, accounting for a sense of consistency in their differentiation patterns. Scrutinizing these choices allows for the discussion of relevant internal contradictions within the text itself, which in turn accounts for its richness and poetic value; they invite us to immerse ourselves into a world of tangled streams of thoughts where life and work crisscross, into a narrative that is neither a proper diary nor a novel. Beyond attempting to assess the degrees of validity of the given translations, this paper focuses mainly on showcasing them as alternative yet equally relevant interpretative stepping stones into Csáth's monstrously complex and tormented literary world.
\end{abstract}

Keywords: Géza Csáth, diary, translation, reception, morphine, sexuality

Biography: Mateusz Chmurski holds a Ph.D. in Comparative Literature from Université Paris-Sorbonne and the University of Warsaw. His dissertation is entitled: Figures of Modernity: Text Theory and Practice in CentralEuropean Literatures (1900-1914) Through the Works of Karol Irzykowski, Ladislav Klíma and Géza Csáth (2012). His research interests focus on comparative approach to Czech, Hungarian and Polish modernist literature, especially in Galicia, Prague and Vojvodina; diary studies, multilingualism, as well as Frédéric Chopin's reception. With Ewa Paczoska, he recently edited a special issue of the Philosophical-Literary Review, published by the Academy of Fine Arts in Warsaw, the Institutes of Philosophy and Polish Literature of Warsaw University, entitled Modernism(s) in Central-Eastern Europe (2013). He is currently preparing a new French edition of Karol Irzykowski's novel The Hag, to be published this year, a volume on Vojvodina's literary heritage, as well as a new Polish anthology of Csáth's works. 
Chmurski, Mateusz. "From Autobiography to Fiction, or Translating Géza Csáth's Diary from Hungarian to French and to Polish." Hungarian Cultural Studies. e-Journal of the American Hungarian Educators Association, Volume 6 (2013): http://ahea.pitt.edu DOI: 10.5195/ahea.2013.113

The aim of this paper is to analyze the complex relation between autobiography and fiction in the work of the Hungarian psychiatrist, writer and music critic Géza Csáth (the pen name of József Brenner [1887-1919]), in particular his 1912-1913 diary, usually called the morfinista napló [diary of a morphine addict], by comparing its Polish and French translations as a means of highlighting alternative interpretations of the diary itself. The choices made when translating such a fragmented text a priori already constitute an interpretation of them. In the case of diaries, and of this diary in particular, comparing different translations can be an excellent way of showing equally plausible divergences of interpretation of the diaries' meaning, assumed "purpose" and general structure.

The perspective of my study reveals how life and work crisscross in a narrative that is neither a proper diary nor, in essence, a novel, neither an autobiography nor a fiction, nonetheless obsessed with both forms, intertwining them and constantly wavering between existential extremes, while, at the same time, raising for the reader the issue of genre in every sense of the word. Scrutinizing translators' choices is thus a particularly engaging way to underscore not only potential contradictions in terms of translation techniques and subjective readings but also the internal contradictions within the text itself, which account for its richness and poetic value. Evaluating the validity of these translations is not the center of focus here, but rather attempting to present them as alternative yet equally relevant interpretative stepping stones into Csáth's very complex and tormented literary world.

Géza Csáth was a Hungarian psychiatrist, writer and music critic, and cousin of famous writer Dezső Kosztolányi. Born in Szabadka-Subotica in Austro-Hungarian Vojvodina, today a part of the Republic of Serbia, he began writing his diary at the age of ten and published his first texts at the age of sixteen. In 1904, he came to Budapest to study music, but after the refusal of his candidature by the Academy, he chose medicine and became a psychiatrist.

Csáth was one of the first in Hungary to eagerly follow the discoveries of Sigmund Freud and those of Carl Gustav Jung. He wrote a book strongly inspired by Jung's doctoral thesis, $A z$ elmebetegségek pszichikus mechanizmusáról [On the Psychic Mechanisms of the Mentally Ill], better known under the title Egy elmebeteg nö naplója [The Diary of a Madwoman], and a few other medical articles. His best known works are five volumes of short stories published from 1908 to 1913, collected today by Csáth scholar Mihály Szajbély under the title Mesék, amelyek rosszul végzödnek [The Stories without a Happy Ending]. He also wrote a few plays, and numerous musical reviews and essays. In 1910, Csáth became addicted to morphine, a condition that afflicted him for the rest of his life and could have contributed to the murder of his wife and his suicide in 1919. Later in the century, many Hungarian authors such as Péter Esterházy, Miklós Mészöly and Ottó Tolnai dedicated extensive writings to his life and work.

In order to grasp the character of the 1912-1913 diary, one has to begin by returning to Csáth's arrival to Budapest in 1904 as commented by him in a sketch for a novel entitled $A z$ ujj nemzedék [The New Generations]. It was a variation of an idea that he dreamt of since the age of 16 (Csáth 2007a: 48):

I. Sept. Budapest. Choc. Groping around. City map. Nocturnal tossing. First walks.

Freedom. Visiting the relatives. Letters home.

II. Oct. University. Looking for books. Theaters. Libraries. University attendants. Streets and coffees.

III. Dec. After learning. To him! Care! Envy! ([unreadable word] "Mihalkovics' Splanchnological part isn't good".) Weakness feeling. 
Chmurski, Mateusz. "From Autobiography to Fiction, or Translating Géza Csáth's Diary from Hungarian to French and to Polish." Hungarian Cultural Studies. e-Journal of the American Hungarian Educators Association, Volume 6 (2013): http://ahea.pitt.edu DOI: 10.5195/ahea.2013.113

IV. Brothel. Successes. Women. (University. Theater. Coffee measuring). Ladies of the house. Florists. Music. Music. Music. University in the saddle. Begins to see. Cigarettes.

[I. szept. Budapest. Schock. Tapogatódzás. Térkép. Az éjszakai hánykolódások. Az első séták. A szabadság. A rokonok látogatása. Levelek haza. / II. okt. Az egyetem. Könyvkereskedések. Színházak. Könyvtárak. Tanársegédek. Utcák, kávéházak. / III. dec. Tánulás után. Neki! Szorgalom! Irigykedés ([olvashatatlan szó] ,,Mihalkovicsnak rossz a zsigertani része.") Gyengeség érzése. / IV. Kupleráj. Sikerek. Nök. (Egyetem. Színház. Kávémérés.) Háziasszonyok. Virágáruslányok. Zene. Zene. Zene. Az egyetem nyeregbe.

Látni kezd. Cigaretta]

(Géza Csáth, Az új nemzedék in Szajbély 2004: 77-78).

In fact, contrary to Csáth's expectations, everything does change for him at that time. Having failed the entrance exam for the Music Academy, he refuses to begin law studies - a path encouraged by his father-and chooses medicine. He seeks new inspirations, from Ernst Haeckel's monism to Freud, whom he was eagerly reading from 1904 to 1906. Almost literally entering the narrative himself, he assigns his own Budapest address (Ferenc körút 44) to the hero of his (unwritten) work. His dreams of writing a novel were in part inspired by the great Mór Jókai, one of his favorite authors, yet also by the controversial Émile Zola, whom he even portrayed in his diary (Csáth 2007a: 109). Csáth, however, never did write that great novel; rather, as Frigyes Karinthy put it in his obituary of Csáth, it was his real life that became a "Hungarian novel," "romantic and unbounded" [az élete magyar régény volt, romantikus és szeretlen], one that ends with the tragic murder of his wife, Olga Jonás, and the author's suicide.

\section{Csáth's (double) intoxication's esthetics}

The discovery of Csáth's diary or, rather, diaries (since its text has been fragmentally published through years by different editors), is a specific story in itself. Its manuscripts were conserved in the Kosztolányi's family villa in Palics, near Szabadka-Subotica, where both Kosztolányi and Csáth were born. Those documents were found by the Vojvodine journalist Zoltán Dér (1928-2007) in 1945, right after the war, and conserved unpublished almost until his death. It is only after the discovery of the 1912-1913 diary, published in 1988 in Novy Sad-Újvidék by the Híd literary review and in 1989 as a book by Babits Kiadó in Szekszárd, that Dér also decided to publish Csáth's subsequent diary part in his possession, i.e. the notes on his fight with addiction written during the First World War (Csáth 1997), and, later on, the diary from 1897 to 1911 (Csáth 2005, 2006, 2007). Today, all the manuscripts-i.e. 1,429 naplók [diary] folios in 20 notebooks and 841 folios in 18 more notebooks with his notes - are archived in the Petőfi Museum (Csáth 1919a-b); yet, their important sections still remain unpublished. Fortunately, a complete edition of the diary is currently being worked on by Mihály Szajbély.

The incredible extension of Csáth's diaries could be a proof that, as Catherine Bogaert and Philippe Lejeune claim in their recent studies, diary writing is a phenomenon that exceeded literature and should be defined first and foremost as a practice that embodies itself in material form; the text of the diary alone remains only a layer among the two others, i.e. the writing process in itself and the diary as object. From the particular rhythm of adding new notes to the types of materials that are selected, diaries play an important role in their authors' lives. Writing a diary means not only noting some text in a relatively regular way, but also structuring time through writing while possibly becoming attached to the manuscript as if it were capturingeven possibly embodying - a part of one's life experience, thoughts and emotions. The French- 
Chmurski, Mateusz. "From Autobiography to Fiction, or Translating Géza Csáth's Diary from Hungarian to French and to Polish." Hungarian Cultural Studies. e-Journal of the American Hungarian Educators Association, Volume 6 (2013): http://ahea.pitt.edu DOI: 10.5195/ahea.2013.113

Swiss Henri-Frédéric Amiel's diary of 16,847 pages from 1839 to 1881 is a good example of how an author might become attached to diaristic writing as a practice: he sewed his diary notebooks himself and travelled everywhere with a chest containing all his previous notes. While Amiel began his diary at the age of eighteen, Csáth started his at the early age of ten:

30th April 1897 Friday This morning the weather was lovely. I went to the school in the morning, stayed there until $11 \mathrm{am}$. In the evening I repeated my Hungarian lesson. Now I am already sitting here at the table after dinner, my father is writing staves and smoking a pipe.

\section{[1897 ápr 30 Péntek Ma reggel gyönyörü idö volt. Reggel az iskolába elmentem 11 óráig ott maradtam. Délután magyarból feleltem. Most már itt ülök az asztalnál vacsora után az Apuka kottát ír és pipázik]. \\ (Csáth 2005: 11. Underlining according to manuscript, Csáth 1919a).}

Even if it is in a very naïve way, the beginning of Csáth's diary already shows his relation to the text and the rules that are to shape all of his future diaristic writings, a practice that can be described as a self-reflexive yet identity-halting narrative. Shifting from meditative introspection to medical observation, his diary can be seen as a particularly sharp and truthful mirror which allows him to become more conscious of his own existence and evaluate his well-being, to "see himself (through) writing." At same time, Csáth's deliriums, his plays on words and on literary conventions, along with the seemingly out-of-control outgrowth of his writings in terms of form and content all actually converge into attaining the opposite effect: an oniric, if not intoxicating, state of self-forgetfulness, a playful interlude in his life when, one might say, "he is nothing (but text)." Repeating self-referential comments, Csáth negotiates his relation with the text; from the first one quoted here to notes that open the 1912-1913 diary. Furthermore, as he repeats similar notes, he observes as continuity is being established in his diary notebooks. In some sense, they become a chronicle of teenage life in separate sections such as weather, health, writing, family life, and so on. Thus, a few months later, Csáth feels that he is supposed to explain himself to his diary (i.e. to himself): "(On $29^{\text {th }}$ March 1898 I am writing this diary that deals with my illness because my illness didn't allow me to [...])" [(ezt a naplót, amély betegségemröl szól, 1898 Március 29en írom mert a betegségem nem engedte ezt (...)] (Csáth 2005: 42). In other words, he becomes progressively aware of the role diary practice plays in his everyday existence.

As he established continuity in his writing by constant repetition of everyday details, Csáth understood that he had established an individual model of writing his life, in some sense an unwritten contract with his notebooks. He gained self-assurance and permitted himself to open his notes on more difficult issues, such as his relationship with his stepmother and, later on, with his mother, Etelka Decsy, who had died when he was eight: "Today's the day when three years ago our Mother died. I was outside with my daddy, at the cemetery, now I am reading one of the Mór Jókai's novels, Greek Notebook [sic]" [Ma 3 esztendeje hogy Anyikánk meghalt. Kinn voltam apuskával a temetöben mostolvasom a Görög Füzet Jokai Mór regényeinek egyiket.] (Csáth 2005: 36). Almost every anniversary of his mother's death is celebrated in the diary, and even her signature is pasted at the end of one of the diary notebooks (Csáth 1919a, 3 III fo 131r; e.g. anniversaries: Csáth 2006: 8; Csáth 2007a: 36; Csáth 2007b: 33). The parallel referring in the same phrase to his mother's death and Jókai's Görög tüz might be seen as a first symbolic crisscrossing of Csáth's biographical intimacy with his literary fascinations. Later on, he not only comments on weather and daily menus, school successes and failures, but also on his sexual life, 
Chmurski, Mateusz. "From Autobiography to Fiction, or Translating Géza Csáth's Diary from Hungarian to French and to Polish." Hungarian Cultural Studies. e-Journal of the American Hungarian Educators Association, Volume 6 (2013): http://ahea.pitt.edu DOI: 10.5195/ahea.2013.113

from his nocturnal emissions to his visits to Budapest brothels. He writes without any selfcensorship and with such intensity that it would seem that he is re-living these events and that there was no difference between his writing and his experience. This unity between the real and the symbolic, text and experience, can be depicted as a multiform, if not monstrous, text-body, a concept particularly relevant in the light of Csáth's emphasis on psychosomatic considerations in his diary.

Today, observing the development of his writings from the beginning to 1903-1904, followed by its sudden decrease at the moment when he arrives in Budapest, the precise moment when he starts using a literary pseudonym shows how the progressive deterioration of his writings in terms of structure and quantity becomes a premonition to his later crises, including his morphine addiction (Kosztolányi noted in the obituary that he wrote for Csáth that "morphine is never a reason, always a consequence" [A morfinizmus mindig okozat és nem ok]). In other words, the diary might be a sign that Csáth's life had begun to fracture very early, probably as early as the loss of his mother. When he came to the Hungarian capital, he seems to have led a somewhat balanced lifestyle for a while, he began to publish his first stories with success, discovered Freud, brilliantly studied at the medical university, visited brothels on Bástya Street - and interrupted his diary. The fracture in notation after 1904 is a trace of initial unity between himself and his writings built through years and then, after his arrival to Budapest, suddenly lost. Csáth's eagerness in writing, growing in many different directions (musical critics, short stories, essays, plays, scientific studies) can be seen in the light of his lifelong search for an existential narration - in the sense of a writing form that would be him - in continuity with his earlier diaristic practice. Here also begins his dream of an autobiographical novel, a novel that he never wrote.

The fracture in Csáth's diary practice might be seen as parallel to the fracture of his life that occurred when he first came to Budapest. His more or less normal life was dramatically altered, and this may have made him more eager to write in order to find some relief by confiding to his diary as he did in the past.

The 1912-1913 diary can be seen as one of the results of Csáth's search for a form of narration that could replace his earlier diary writing, for it shows how Csáth's life and work intertwine in a puzzling manner. The text of Csáth's diary consists of three parts. It begins with Feljegyzések az 1912. évi nyárról [Notes on the Summer of 1912], an intradiegetic first-person narrative on a spa doctor's sexual exploits, in which every new woman is supposed to be, as Csáth claims, a "new chapter." However, already the first lines emphasize the text's fictional character and might be read as a provocative ars poetica, i.e. an attempt to define a new form of narration on the author's life and work (see Varga 2011):

A terrible and depressing thought: I no longer have any inclination to write. Since I began to work penetratingly with analysis and to examine my unconscious spiritual life in all its facets, I have no more need to write. Yet analysis only brings suffering, bitter recognition, and disappointment, while writing brings joy and sustenance. But still I can't! I write with difficulty, anxiously. The thought is killed in the bud by criticism. And I can't put my innermost, unsettled affairs onto paper. I am inhibited by the feeling that others can read between the lines as clearly as I - the psychoanalyst — can read into the writing of other authors. Nevertheless, with iron will, I force myself to write. I must write. Even if writing will never be my life's work again, at least it should be fun. I must play, even if I can't enjoy myself, because it's the only chance I have of ever making a lot of money. 
Chmurski, Mateusz. "From Autobiography to Fiction, or Translating Géza Csáth's Diary from Hungarian to French and to Polish." Hungarian Cultural Studies. e-Journal of the American Hungarian Educators Association, Volume 6 (2013): http://ahea.pitt.edu DOI: 10.5195/ahea.2013.113

(Csáth 2000: 17-18).

[Rettenetes és nyomasztó gondolat, hogy nincs többé kedvem az íráshoz. Mióta az analyzissel behatóan foglalkozom, és minden ízében elemezem az öntudattalan lelki életemet, nincs többé szükség rá, hogy írjak. Pedig az analyzis csak szenvedést hoz, keserü életismeretet és kiábrándulást. Az írás pedig gyönyört ad és kenyeret. Mégse! Nehezen megy, aggályokkal. A születö gondolatot mintegy csírájában megöli a kritika. A legbelsö elintézetlen ügyeimet pedig nem tudom papírra tenni. Az az érzés gátol, hogy mások éppolyan tisztán olvasnak benne, mint én az írók írásaiban, én, a psychoanalitikus. - Mégis vaserôvel kényszeritem magam, hogy irjak. Írnom kell. Ha nem is lesz számomra többé az irás életmüködés soha, legalább legyen játék. Játszanom kell, ha nem is mulatok, mert ez ad csak esélyt rá, hogy valaha sok pénzt keressek.]

(Csáth 1989: 5).

Even if the personal tone of the opening might seem credible, it is also very surprising that the diary begins with such an unusual and provocative overture, announcing the character of the following notes and setting up the tone for a constant oscillation between the autobiographical and the fictional. Reading Csáth's diary, one can easily forget that it is a fictional work, dealing not only with medicine and drugs, but also with Casanova or Wagner (that the doctor-author plays naked on the piano after intercourse). This fictional aspect of his diary becomes clear as early as in the first part:

The chambermaid! This is a new chapter. Short but poignant. She was 36-year old, bignosed nymphomaniac, procuress for the chambermaids, with huge buttocks, slightly sagging but beautiful breasts, masterfully formed on the whole, with velvet-smooth pink skin. Her brutal healthiness and terrible sensuality captured my attention, calling to mind a Bacchante. On one occasion I saw her in the baths. The wet bathing suit clung to her skin and revealed splendid curves. (...) I intended to be completely loyal to my Olga [i.e. Olga Jonás, Csáth's wife since 1913, murdered by him in 1919] in our married life, and this type of woman had never appeared on my menu. At noon of $19 \mathrm{July,} \mathrm{I} \mathrm{trapped} \mathrm{her} \mathrm{in}$ my room.

(Csáth 2000: 47).

[A szobaasszony! Ez új fejezet. Rövid, de velös. Egy 36 éves, testes, nagy orrú nymphomániás nö volt ez, a szobalányok keritőője, óriási seggel, kissé lógó, de szép mellekkel, egészben mesteri megromlás és bársony sima, rózsaszín bör. Brutális egészsége és rémes érzékisége, amely egy bacchánsnöére emlékeztetett, keltették fel figyelmemet. Egy alkalommal a fürdöben láttam. A nedves fürdöruha szorosan tapadt hozzá, és pompás idomokat mutatott. A csípök megalkotása, a hátba való áthajlása, az egész test egészében ritka szép volt. Ekkor határoztam el, hogy komolyan hozzálátok a megszerzéséhez, annál is inkább, minthogy házaséletemben teljes hüséget óhajtottam majd Olgám iránt meghonosítani - és ez a typusú nö még sohase szerepelt menümön. Júl. 19-én történt, hogy szobámban egy délben elfogtam].

(Csáth 1989: 33).

The many stories of this type reveal the (real or accomplished) sexual fantasies of the author, a "would-be" Casanova, as Arthur Philips puts it (Csáth 2000: 5). This "would-be" character within the autobiographical narrative seems far more likely to be fictional, in particular if we consider the extremely masculine character of Csáth's discourse when exposing the male 
Chmurski, Mateusz. "From Autobiography to Fiction, or Translating Géza Csáth's Diary from Hungarian to French and to Polish." Hungarian Cultural Studies. e-Journal of the American Hungarian Educators Association, Volume 6 (2013): http://ahea.pitt.edu DOI: 10.5195/ahea.2013.113

(sexual) potential. In Csáth's diary, women exist only as objects of desire, soon replaced by others, and described only externally. They are only bodies, not persons, they are projections necessary to his chauvinist vision of masculine power rather than characters of his narrative (see Gergely Angyalosi's and Zoltán Németh's analyses). Yet, Csáth's twofold desire for sexual accomplishment and career soon merges with morphine addiction. Without any transition, the second part of his diary moves on to more typical diaristic notes consecrated to the fight against his drug addiction:

12.15 a.m. Today I begin a new era in my life. I must give up my M[orphine] habit for good and relegate use of $\mathrm{P}$ [entapon, ersatz to morphine, $\mathrm{MCh}$ ] to rare instances. In the last two days, there have been symptoms indicating that my system craves a serious increase in dosage. I must therefore put an end to the perilous game. (Csáth 2000: 115).

[- Reggeli 1/4 1. A mai nappal új korszakot nyitok meg életemben. Végképp le kell szoknom az M-röl, és mint ritkán használt szert kell szabályoznom a P vételét. A két utolsó napon olyan tünetek mutatkoztak, amelyek arra engednek következtetni, hogy a szervezet most a dosisok nagyfokú emelését követelné. Végét kell tehát vetnem a veszedelmes játéknak.]

(Csáth 1989: 93-94).

Regardless of the author's plans, the "perilous game" he speaks of continues. Is it a play of self-revelation and hiding or rather a game of drugs and sexuality? Regardless of the answer, the last part of the diary consists of a separate text, Morfinizmusom története [The Story of My Morphine Addiction], accompanied by a few notes and three annexed documents addressed to Csáth's cousin, Kosztolányi, as it was his wish that the latter would tell his story in a novel: Jegyzetek D-nek [Notes to D.], Általános megjegyzések [General Remarks], Desirének [To Desiré]. No more provocative narration on sexual life in this latter part of the diary, but only despair.

Hence, no wonder that Csáth's "morphinomania diary"-replete with descriptions, ranging from sexual ecstasies to drug-addict depression, surrounded by the aura of the author's biography made of brilliant beginnings followed by tragic events including murder and suiciderapidly became a sensation, discussed by writers, researchers and critics (e.g. Éva Hózsa, Zoltán Farkas or László F. Földenyi). In the late 1980s, Csáth's legend was already rich, founded on short stories dealing both with the dark side of human existence in contrast to recollections of happy childhood memories, as well as a psychoanalytic study from 1911, On the Psychic Mechanisms of the Mentally Ill [Az elmebetegségek pszichikus mechanizmusáról], just as the diary better known under another title, The Diary of a Madwoman [Egy elmebeteg nö naplója] (Csáth 1978). Because of the diary's particularly explicit themes, or perhaps because the original text had mysteriously disappeared (the text was published from a typescript version) - the 19121913 diary only strengthened the author's reputation as one of the finest examples of the Hungarian fin-de-siècle tormented soul, the cursed poet, an incarnation of both the Marquis de Sade and Casanova (see Keresztúrszky 1997).

In some sense, Csáth's legend developed according to the rhythm of their translation/publication after his death: his short stories or musical critics were known and republished since 1950, later the reedited psychiatric studies increased interest in Csáth, that finally led to publishing his diary parts; it is only today that their complete edition is being prepared. Based on The Diary of a Madwoman and morfinista napló, Jánosz Szasz' film Ópium. 
Chmurski, Mateusz. "From Autobiography to Fiction, or Translating Géza Csáth's Diary from Hungarian to French and to Polish." Hungarian Cultural Studies. e-Journal of the American Hungarian Educators Association, Volume 6 (2013): http://ahea.pitt.edu DOI: 10.5195/ahea.2013.113

Egy elmebeteg nö naplója [Opium: Diary of a Madwoman] (2007) could be seen as this legend's visual equivalent. After the German translation of the diary in 1990, Csáth's fame spread all over Europe, as further translations were also published in Serbian (1991), Italian (1998), Polish (2001), English (in Budapest, 2002), Bulgarian (2005), Macedonian (2007), and Spanish and French (2009). In many translations, the diary's usual name was chosen as a (sub)title, even if it never appears in the text itself.

\section{(Completing) the incomplete in Csáth's diary}

Thierry Loisel, Csáth's diary French translator had a particularly bold strategy when he chose the title Dépendances. Journal 1912-1913 [Addictions: Diary 1912-1913]. Besides the title, the reader's expectations are further directed by several other very explicit indications, such as the book's cover image by Jean-Michel Perrin where a doctor is listening to his own chest while having an intercourse with one of his patients, and, by the blurb on the back cover, which, in the first words, advertises Csáth as follows:

Erotoman, Graphomaniac, Morphine addict. Each of those attributes defines at one moment or another Géza Csáth's character, the man with multiple addictions. (...) In his diary finally translated into French, we discover the hidden face of this brilliant writer so peculiarly passionate about torturing himself.

\section{[Érotomane. / Graphomane. / Morphinomane. / Chacun de ces qualificatifs définit à un moment ou un autre la figure de Géza Csáth, homme aux multiples dépendances. (...) Avec son journal enfin traduit en français, on découvre la face cache de cet écrivain génial qui mit à se torturer une passion toute particulière]. \\ (Csáth 2009: back cover).}

Through an advertising strategy based on added paratextual elements that form a large frame for the main text, the French translation plays in a very explicit way with Csáth's sexual and addictive side using a psychological contrast inspired by Dr Jekyll \& Mr Hide. Loisel is a French translator known for his earlier edition of Kosztolányi's Nero, a véres költö [The Bloody Poet. A Novel about Nero] (2011). His Csáth volume is a complete edition of all the three parts of morfinista napló, accompanied by a long preface by the translator (5-37) and an afterword written by Jean-Philippe Dubois, a contemporary French psychoanalyst. The small volume was published by L'Arbre vengeur, an editing house that specializes in forgotten as well as "exotic" writers from all over the world. Three years earlier, the same company published a selection of Csáth's short stories, Le Jardin du Mage [A Magician's Garden], also illustrated by Perrin (Csáth 2006). Loisel considers Csáth's diary as - to quote once again the book cover - " an exceptional literary work born on the fringe of babbling psychoanalysis" [une cuvre littéraire exceptionnelle née en marge de la psychanalyse balbutiante]. Yet, he suggests that we are dealing with an autonomous literary work, speaking in his foreword of the diary's "remarkable homogeneity" [homogénéité remarquable], due to "a spiral writing" [une écriture en spirale] (20-25).

Considering the text as almost a particular variation of Imre Madách's The Tragedy of Man, the translator is convinced that, in 1912, Csáth already felt his own approaching death to such extent that his "diffuse despair" [désespoir diffus] might explain the diary's "testamentary character" [caractère testamentaire] (31). Hence, it might seem that Loisel sketches a common plot between Csáth's life and work as if it were some kind of Shakespearian tragedy, in which the 1912-1913 diary or events like his marriage are supposed to be an overture, while the author's personal crisis and war diaries become a logical development before Csáth's final act of suicide in 1919. Thus, the translator indirectly transposes his interpretation on the text, adding 
Chmurski, Mateusz. "From Autobiography to Fiction, or Translating Géza Csáth's Diary from Hungarian to French and to Polish." Hungarian Cultural Studies. e-Journal of the American Hungarian Educators Association, Volume 6 (2013): http://ahea.pitt.edu DOI: 10.5195/ahea.2013.113

not only the new title as well as a complex paratext but also organizing the diary as if it consisted in three acts, "1912," "1913" and "Three annexes" [Année 1912; Année 1913; Trois annexes], when, in the original, there is no clear distinction between the parts. By this reorganization, Loisel seems to suggest not only a chronological development, but also a causal development that led to Csáth's tragic finale.

In the contents of the volume, he treats the Notes on the Summer 1912 and the following diary notes as if they were equivalent chapters ("September 1912", "October 1912" and so forth [Septembre 1912; Octobre 1912], 117, 148). However, there is no direct proof that the "three annexes" were written later than the diary itself. Csáth did leave to Kosztolányi a very poignant note before his death: "young people have to learn from my novel, doctors, too, but most of all, men! Future husbands! Write a 500-pages novel and publish it..." [Tanuljon regényemböl az ifjúság, az orvosok, de föleg a férfiak! A házasulandók. Írd meg egy 500 oldalas regénynek és add ki...] (Balogh 2004: 1404) but to interpret this statement as Csáth's literal "last will and testament" is highly questionable.

J.-P. Dubois' afterword to Loisel's translation begins by comparing Csáth with other authors inspired by Freud (258), even if, in his eyes, doctor Brenner was never a true pupil of Freud because he had "too much lucidity as far as his psychic troubles and fragilities are concerned" [une trop grande lucidité à propos de l'ampleur de ses difficultés et fragilités psychiques] (259), therefore, he developed — as Dubois states - a form of "paranoiac destructiveness" [destructivité paranö̈aque] against himself, to which the diary is supposed to be a "cruel testimony" [un témoignage cruel] (260) written from the position of an "observer/observed" [observateur/observé] (267). Observing himself, the Hungarian author through his diary as another psychoanalytic case, Dubois reads the text almost literally, mostly disregarding its fictional dimension, he considers e. g. that "Csáth soon takes on his patients" [Csáth s'attaque bientôt à ses patients] (263). Loisel, and especially Dubois, seem to forget that Csáth was not only an obsessively self-documenting morphine and sex addict, but also a creative author trying to liberate and express himself through writing. In fact, the way he projects himself through his notes resembles what Jean-Marie Schaeffer calls "fictional immersion" [l'immersion fictionnelle]. Even if it is plausible that Csáth is telling mostly the truth, the diary alone cannot be a sufficient proof. Embracing the fictional and creative aspects of his writings helps us see Csáth not only as a subject but also as creative hero/narrator of the events depicted in his diary.

In contrast to Loisel's French translation, the Polish edition of two long fragments of Csáth's 1912-1913 diary by Anna Górecka seems less directive in terms of interpretation. Górecka, a translator known for her editions of such different authors as Sándor Weöres, Attila Bartis, Frigyes Karinthy and Imre Kertész published the work in the 2-3/2001 issue of the review Literatura na świecie [World Literature], in a number which also contains seven of Csáth's short stories; another fragment of Csáth's diary from 1915 and a short presentation of the writer himself by Elżbieta Cygielska (Csáth 2001). Unfortunately, there are no notes from Csáth's 1913 diary and his previously-quoted diary beginning was also omitted, along with the three last additions to the text addressed to Kosztolányi. Thus, the reader does not know the end of Csáth's story until he reads Cygielska's article, a useful biography, enriched with quotations from and on Csáth and suggested parallels between him and his contemporary writers, Artur Schnitzler and Georg Trakl. All in all, compared to the French translation this partial Polish edition is comparatively more reserved and allows the reader to build his own opinion on the diarist-author Csáth. Yet, one may wonder why Górecka, who translated only part of the 1912-1913 diary, specifically chose to include a portion of Csáth's 1915 notes dealing mainly with the author's 
Chmurski, Mateusz. “From Autobiography to Fiction, or Translating Géza Csáth’s Diary from Hungarian to French and to Polish." Hungarian Cultural Studies. e-Journal of the American Hungarian Educators Association, Volume 6 (2013): http://ahea.pitt.edu DOI: 10.5195/ahea.2013.113

struggle with addiction in this edition. Could it be that the inclusion of these texts was meant to reinforce the importance of the writer's fight with morphine and psychoanalytic self-analysis, and a way to present these aspects of his work as leading threads to the diary as a whole? The 1915 part of the Polish translation was taken from Csáth's war diaries, more and more focused on his fight with morphine. An essay by Mihály Szajbély that closes their Hungarian edition might have indirectly hinted at not only the choice by the Polish translator to include the 1915 diary, but also the idea that Csáth's texts may be perceived as a (psychoanalytical) endeavor. Szajbély discusses that, to doctor Brenner, Freud was of equal importance as Copernic or Darwin, and that it was for this reason that Csáth decided to posthumously pass his brain to Doctor Gyula Schuster for a histological analysis. His diary could thus be seen as an intellectual examination of his mind through writing similar to the medical dissection to which he destined his brain to be submitted. In Csáth's notes:

Light and shade metaphors are not only counterpoints; from a psychological point of view they authenticate one another. It is in the light of the idyll that the present seems to be so desperately dark, and it is because of this darkness that the idyll is so desired. The vibrating tension between those two poles is perhaps the main reason (...) why we can appreciate the diary not only as a biographical document, but also as a literary work (...).

[A napfény és a sötétség képei nem csupán ellenpontozzák, hanem lélektanilag hitelesítik egymást. A jelen az idill perspektívájából tünik reménytelenül sötétnek, az idill a jelen sötétjéböl olyannira kívántosnak. A közöttük vibráló feszültség pedig egy-egy részlet különös megmunkáltságán túl talán a legfontosabb oka annak, hogy a napló szövege nem csupán életrajzi dokumentumként élvezhetö, hanem sajátosan ágasbogas, szabálytalan szépirodalmi alkotásként is].

(Szajbély 1997: 316).

As the following excerpt will illustrate, the fictional and autobiographical dimensions of Csáth's texts seem to be represented in different ways in the Polish and French editions, not only in terms of structure but also in the translations themselves (the following excerpt is Reich's English version, the Hungarian, Górecka's translation, Loisel's translation):

During this time, we slept poorly. Especially on days without P, sexual desire troubled me too. Recent trysts would replay themselves in my imagination with almost painful accuracy. I saw Olga as she walked to and fro my room, in a shirt, as she bent at the waist, and the flesh of her little legs glowed through the thin black stockings.

That's how I came, not long afterwards, faute de mieux, to seduce the hotel chambermaid, named Terez or something of the sort. I banged her a few times with a condom, because she had quite a tight vagina. Her virginity had been taken two years before by the spa's Dr Mahler. This 21-year-old girl with her thin, pale body was not an appetizing morsel, but as soon as her vapid blue eyes grew inflamed by lust, as soon as her face blushed and she started to make violent counter-thrusts, there was something interesting in that. Dezső tried communing with her as well, but the boy's penis drooped, and he called off the attack in vexation. (22-23)

[Ez idöben nehezen aludtunk. Különösen a P-mentes napokon bántottak engem is a szexuális vágyak. Olykor szinte fájdalmas tökéletességgel jelentek meg a képzeletemben nemrég múlt idök pásztorórái. Láttam Olgát, amint ingben ide és oda jár a szobámban, amint hajladozik a dereka, és apró lábainak húsa átcsillan a vékony, fekete harisnyán. 
Chmurski, Mateusz. "From Autobiography to Fiction, or Translating Géza Csáth's Diary from Hungarian to French and to Polish." Hungarian Cultural Studies. e-Journal of the American Hungarian Educators Association, Volume 6 (2013): http://ahea.pitt.edu DOI: 10.5195/ahea.2013.113

Így történt azután, hogy hamarosan "feau de mieux", a szállodai szobalányt, valami Teréz nevüt csábitottam el. Condommal néhányszor erösen meglöttem, mert igen szük vaginája volt. Szüzességét Mahler szanat. orvos vette el 2 év elött. Ez a 21 éves lány a maga sovány, sápadt testével nem volt csábitó falat, de amint kitüzesedtek a buta, kék szemei a kéj hatása alatt, amint kipirult az arca, és hevesen ellenmozgásokba kezdett, ebben volt valami érdekes. Dezsö is megpróbálta, hogy áldozzon vele, a fiúnak azonban a penise lekonyult, és bosszankodva hagyta abba az ostromot.] (10-11)

[W tym czasie marnie sypiatem. Zwtaszcza $w$ dni bez $P$ dręczyly mnie straszliwe żądze seksualne. W mojej wyobraźni pojawiały się wówczas z bolesna niemal doskonatościa niedawne idylliczne chwile spędzone z Olga. Widziałem ja, jak w samej koszulce przechadza się po pokoju. Jak wygina się jej kibić, a przez cienkie czarne pończochy prześwituje skóra jej szczuplych nóg.

Wkrótce potem faute de mieux uwiodlem pokojówkę imieniem Teréz. Uzbrojony w kondom kilka razy przebijałem się szturmem, bo miała bardzo waska waginę. Dziewictwa pozbawit ja dwa lata temu sanatoryjny lekarz - doktor Mahler. Ta dwudziestojednoletnia dziewczyna, chuda i blada, nie była zbyt kuszacym kaskiem, ale kiedy $w$ chwilach rozkoszy jej głupie niebieskie oczy zapalały się, a na twarzy pojawiat się rumieniec $i$ zaczynała wykonywać gwattowne ruchy miednica - miała w sobie coś interesujacego. Dezsö również próbował z niq poharcować, ale niestety penis szybko mu zwiotczal, więc wściekty musiat zaniechać szarży.] (41)

[À cette époque-là, nous avions des difficultés à dormir. En particulier les jours où moi je ne prenais pas de $P$, j'étais torturé par le désir sexuel. Mes derniers rendez-vous galants repassaient alors dans mon imagination avec une précision presque douloureuse. Je voyais Olga se déplaçant ça et là dans ma chambre, vêtue d'un simple chemisier, courbant les reins et montrant la chair luisante de ses petites jambes à travers ses fins bas noirs.

C'est ainsi que j'en vins rapidement, feaut de mieux, à séduire la femme de chambre de l'hôtel, qui s'appelait Teréz ou quelque chose de ce genre. Je me la suis prise avec vigueur plusieurs fois après avoir enfilé un préservatif, car elle avait un vagin plutôt étroit. C'était docteur Malher, le médecin du sanatorium, qui l'avait déflorée, il y a deux ans. Cette fille, âgée de 21 ans, avec son corps frêle et pâle, n'était pas un morceau de premier choix, mais dès que ses yeux bleus stupides s'enflammaient sous l'effet du plaisir et qu'elle commençait à s'agiter violemment pour répondre à mes assauts, il y avait quelque chose d'intéressant. Dezsö essaya lui aussi de communier avec elle, mais le pénis du pauvre garçon retomba mollement et, contrarié, il rendit les armes.] (44)

Already in this fragment, which is where the Polish translation begins, important problems arise. First, how to deal with the change in narrative's voice between the first person plural and singular grammatical persons? We know from the full Hungarian text that aludtunk [we slept] concerns Csáth and his brother Dezső (Jász), and in this part Olga is present only "in imagination." Górecka chooses to change the first verb to the first-person singular in the frequentative form sypiatem [I used to sleep] and not spatem [I slept]; Loisel stays in plural and renders the same nuance using the imperfect tense. Both translators look for equivalent grammatical forms in their own language, a task that is easier in Polish, e.g. when it comes to verbal prefixes át|csillan [glow through] can be easily translated as prze|świtują. Secondly, 
Chmurski, Mateusz. "From Autobiography to Fiction, or Translating Géza Csáth's Diary from Hungarian to French and to Polish." Hungarian Cultural Studies. e-Journal of the American Hungarian Educators Association, Volume 6 (2013): http://ahea.pitt.edu DOI: 10.5195/ahea.2013.113

Csáth's language notably includes the use of rather obscure terminology (medical, musical, literary, etc.), and that of foreign languages such as French or, more rarely, German, whereby he maximizes the contrasts in his narration, especially where sexual themes are present. In fact, when Csáth was writing words and expressions as e.g. múlt idők pásztorórái [recent trysts], condommal [with a condom], anatomical terms such as a penis [penis] or French expression faute de mieux, the tension between foreign languages and the Hungarian was much stronger than today. Thus, the difficult task of the translators is to try to render it nowadays, when their controversial nature is no longer what it used to be in the Hungarian, Polish and French societies at the time. Again, those disparities are easier to understand in Polish, where foreign and Slavic terms still function alongside one another and substantives such as penis or idylla exactly equal Hungarian terms. Yet, when it comes to the French expression, Górecka decides to correct his "feau de mieux", whereas Loisel leaves the original and adds a footnote.

In fact, even if he does not have the same liberty and sometimes needs to compensate these language limitations by using different levels, the general tendency of Loisel's version is rather to provide a reader-friendly translation. He chooses to make explicit expressions such as condommal [with a condom] or "P-mentes napokon" [on days without P]: "après avoir enfilé un préservatif" [having put on a condom], "les jours où moi je ne prenais pas de $\mathrm{P}$ " [on days I did not take any P], instead of leaving the reader that aim to guess e.g. what might be "les jours sans $\mathrm{P}$ " [the days without P]. The problem of how to translate enigmatic or taboo words is far more important than it might seem, for Csáth shortens his daily notations as far as sex, morphine or money are concerned; he even develops a particular form of abbreviated notation in "psychosomatic tables" enumerating morphine consumption, weight, sexual intercourses, afternoon catnaps or lectures. At the same time, as Attila Sebestyén states, Csáth even formulated in his essays a theoretical basis for a psycho-somatic observation.

A few psychosomatic tables developed by Csáth have been preserved in the Budapest Petőfi Irodalmi Múzeum Csáth Archive (Csáth 1919a-b), twelve more in the Széchényi National Library (Csáth 1905, 1907, see Chmurski 2013a-b). The originals testify to the fact that such expressions as "days without P" are etiquettes through which Csáth organizes his subjective time perception. He used a system of abbreviation, which included, for example, signs or letters specific for intercourses, masturbation, defecation or his state of mind during different parts of the day; elements that might be called parts of his addiction discourse. In diaries - and in the case of this diary in particular - this peculiar discourse should be conserved, even for the price of (relative) loss in readability. Similar cases are abbreviations, dates or enumerations such as "szanat. orvos" [spa's Dr]. Here, both Górecka and Loisel choose to explain the shortened forms [Polish "sanatoryjny lekarz", French "le médecin du sanatorium"], write numbers in full words, standardize the dates' format. Thus, they diminish the author's hesitations (and the diary's rough character):

[date lacking] A wonderful, unforgettably beautiful day. In the morning I stayed away from the poison. Life gave me a regal reward. In the afternoon, with Olga, from 3:00 $4: 45++++\ldots$ ecstasy that can be called miraculous. Afterwards .024 P. Of that, unfortunately .006 was M. Sublime euphoria. Afterwards home to Olga's place. We ate raw Westphalia ham, Romadour cheese, green peppers, grapes and pears. Than we drank malt beer and Marsala wine. Both of us got drunk and more sympathetic than ever before. She showed the spirit of a girl-child - I was truly awash with joy and fulfillment. She seemed noble and angelic. We said our goodbyes still drunk, luxuriating in love. (105106) 
Chmurski, Mateusz. "From Autobiography to Fiction, or Translating Géza Csáth's Diary from Hungarian to French and to Polish." Hungarian Cultural Studies. e-Journal of the American Hungarian Educators Association, Volume 6 (2013): http://ahea.pitt.edu DOI: 10.5195/ahea.2013.113

[Szept. 23. / Nagyszerü, feledhetetlenül szép nap. Délelött tartózkodtam a méregtöl. Királyi jutalmat adott az élet. Délután Olgával 3-3/45-ig ++++ olyan Lelmosódott, olvashatatlan szól kéjérzésekkel, amelyek csodásaknak nevezhetök. Utána 0,024 P. Ebböl, sajnos, 0,006 M volt. Nagyszerü euphoria. Utána hozzájuk haza. Nyers westphaliai sonkát ettünk, romadour sajtot, zöldpaprikát, szölöt és körtét. Majd malátasört és Marsala bort ittunk. Mint a ketten berúgtunk, és olyan közvetlenül beszéltünk egymással, mint még soha. O. kedves volt és naív, és emellett rokonszenvesebb, mint valaha. Egy gyereklány kedélyét mutatta - valósággal úsztam az örömtöl és megelégedettségtöl. Nemesnek és angyalinak tünt föl. Részegen váltunk el egymástól. Valósággal tobzódtunk a szerelemben.] (84-85)

[23 IX.

Cudowny, niezapomniany dzień. Przed poludniem powstrzymatem się od trucizny. Otrzymatem iście królewska nagrodę. Po poludniu z Olga od trzeciej do kwadrans po czwartej $++++z$ takimi rozkoszami, które można nazwać cudownymi. Potem 0,024 P. Niestety, skończyto sie na 0,006 M. Wspaniała euforia. Wieczór u nich w domu. Jedliśmy surowa szynkę westfalska, ser romadour, zielona paprykę, winogrona i gruszki. Na koniec piwo stodowe $i$ wino Marsala. Oboje byliśmy zawiani i rozmawialiśmy ze soba tak szczerze, jak jeszcze nigdy. Olga byta mita i naiwna, a przy tym sympatyczniejsza niz kiedykolwiek. Zachowywała się trochę jak mała dziewczynka, emanowała radościa $i$ zadowoleniem. Wydawała mi się szlachetna, anielska. Rozstaliśmy się pijani. Tonęliśmy w miłości.] (66)

\section{[23 Septembre.}

Belle, magnifique, inoubliable journée. Ce matin je me suis abstenu de prendre du poison. La vie m'en a récompensé royalement. Après-midi avec Olga de 3 hà $4 h 45 \odot \odot$ $\odot \odot$ avec des sensations voluptueuses tellement [-] que l'on peut dire miraculeuses. Ensuite 0,024 P. Dont, hélas, 0,006 M. Euphorie sublime. Ensuite chez eux. Nous avons mangé du jambon cru de Westphalie, du fromage de Romadour, du poivron vert, du raisin et des poires. Ensuite bu de la bière de malt et du vin de Marsala. Nous étions ivres tous les deux et nous nous sommes parlés avec une grande franchise l'un à l'autre comme jamais auparavant. O[lga]. était gentille et innocente, mais proche aussi, comme elle ne l'avait jamais été. Elle réagissait à tout comme une petite fille - pour dire la vérité, je nageais dans la joie, dans le bonheur. Elle était comme un ange, pleine de noblesse. Nous sommes séparés, toujours ivres. À dire vrai, nous nous étions donnés à plein corps tous les deux.] (136)

The second part of Csáth's 1912-1913 diary consists of notes that might be called proper to diaristic writing as such, i.e. enumerations of daily activities without any further hierarchy. Éva Harkai-Vass proposed to understand this aspect of Csáth's diary through the concept of "antifiction", i.e. memories put on paper in a way to form an archive of existence and not a literary narration. Here, both translators left more of its chaotic character than in the first part of the diary, i.e. noun phrases, short mentions of Morphine consumption or symbols relative to sexual intercourse, reproduced by Loisel in small circles with a point in the center, thus closer to the conserved Csáth's manuscripts than in the Hungarian edition, where the symbol is replaced by a simple plus. Thus, the diary's halting rhythm was better preserved, even if, still, dates were 
Chmurski, Mateusz. "From Autobiography to Fiction, or Translating Géza Csáth's Diary from Hungarian to French and to Polish." Hungarian Cultural Studies. e-Journal of the American Hungarian Educators Association, Volume 6 (2013): http://ahea.pitt.edu DOI: 10.5195/ahea.2013.113

corrected and adapted; Górecka corrects also time notation and develops the shortened form of Olga's name. One can observe how, in the final part of this entry, short, yet eloquent phrases, constitute together the description of the couple's meal, a mark of Csáth's style that reveals itself both in his diary and in his short stories. In earlier entries, Csáth often uses similar lists of the day's menus (e.g. Csáth 2005: 12, 17, 38 etc.), along with lists of guests, school grades, weather conditions; later on, he adds lists of texts that he was working on, texts that he had already published, theater plays or concerts he attended to, trips that he made, books he had read or intended to read, as well as the amount of money he spent, lists of his patients, sexual positions, his own faults and his wife's mistakes - a flow of discourse that seems to culminate in the tables that end his whole diary. The narrowing down of this torrent of information to the halting phrases in the above passage seems to correspond with his life's fastening rhythm.

All in all, Górecka and Loisel offer two distinct translation strategies that could be summed up as exposing-the-incomplete and completing-the-incomplete Csáth's diary. And curiously, it seems that both of them are valid on their own terms; as we have seen, the diary begins as if it were a proper, provocative literary text, yet it ends in distinctive shortening of diary notations, focusing almost exclusively on sex and morphine addictions, that seem to have taken control of the author. At the same time, each translation reveals different traditions in approaching foreign literature, which could be called, "domesticating" and "foreignizing" strategies, i.e. the first understood "not as a representation of another work of literature, but as a representation of the content of another work of literature," implying an "implicit denial of the possibility of differing versions of "content"" and the latter as "insistence on the role of translation as a means of enriching the target language through the introduction of new expressions, forms and ideas" (Cooper 6,11).

Both domesticating and foreignizing translation methodologies have their own merits. In conformity with a supposed "French tradition", Loisel translation could be called domesticating, i.e. one that seems to give a more "literary" version of Csáth's diary. Domestication is an endeavor which does relate with his aspirations and with the initial idea of Notes on the Summer of 1912, a text the author probably wanted to be a text based on his life, yet modified in order to become a provocative literary fiction. Foreignizing translation model could be the one Górecka proposes, following Central-European traductological practices, for she insists on the author's stumbling diction, exposing the text's incongruity. The foreignizing model has the advantage of doing justice to Csáth's diaristic "entropy" and justly presents the 1912-1913 Diary as a fragmented, unfinished attempt. These two dimensions are actually complementary, crucial to the diary's understanding and the tension which Csáth continuously nourished since he started writing at the age of ten and continued writing, up to shortly before his death in 1919, with the last conserved entry dated July 15, 1919.

Because the two translators' strategies can be understood not as strictly opposing but complementary readings of the diaries, they can be used to highlight the richness of Csáth's diary, still open today to speculation in regard to its aims, truthfulness and literary value. Zoltán Z. Varga (2011: 12) stated that, opposing the morphine-addict diary and the memoir that Csáth began writing at the same time, he tried to find a new genre based on an "form of associative narration" [egyfajta asszociatív történetmondás]. In both forms, the diary and the memoir, Csáth searched to find a new model of writing that could encompass his life split in two, both through the more coherent narrative of the memoir and through the parallel diaristic enumeration of events that could be understood as a kind of existential graph. Yet, the attempt to formulate an innovative narration on himself - and for himself - could already be observed in much earlier in 
Chmurski, Mateusz. "From Autobiography to Fiction, or Translating Géza Csáth's Diary from Hungarian to French and to Polish." Hungarian Cultural Studies. e-Journal of the American Hungarian Educators Association, Volume 6 (2013): http://ahea.pitt.edu DOI: 10.5195/ahea.2013.113

Csáth's works, not only in the form of a diary, but also e.g. in short stories. In fact, they might be understood as a play with elements of autobiographical narration spread in the fictional text. The medical profession of many heroes, places related to his life, family relations similar to the ones Csáth had, all these elements might be seen to be setting up an "autobiographic space" as defined by Lejeune. Furthermore, similar aspects might be seen in the "semi-literary and semipsychiatric" [félig irodalmi, félig pszichiátriai] psychoanalytical study by Csáth, as Pál Harmat puts it (140), where the story of Miss Gisela, doctor Brenner's patient, has many similarities with his own one and it seems he did not chose this precise case for his analysis by accident. Writing a diary herself, she has a deep fear of tuberculosis, just as Csáth did; it happened that it was a false diagnosis of this very illness that made him inject himself with his first morphine dose. These fragments of text, scientific or literary, autobiographic or fictional, belong in some sense to one single chaotic world which he tried to build while wandering in search for of his (textual) identity. If we invert the three parts' order in the 1912-1913 Diary, we observe the juxtaposition of "proper" diary entries (1913), semi-fictional and semi-autobiographic notes (1912) and an attempt in autobiographic fiction (Notes on the Summer 1912). Yet, it is only at the end of this particular structure that Csáth uses the third-person omniscient voice, as if to say he finally found the form he seeked for all of his life. Yet, this form serves him only to deplore the past:

3. Degenerated birth should also be stressed. Illusions about the deceased mother. The boy is devoted to his father; however, certain matters lead to perpetual misunderstandings.

4. Ambition that is too great, then suddenly broken, should also be stressed (149)

[3.) Hangsúlyozandó a degenerált születés. Illúziók a megholt anyára. A fiú ragaszkodik az apához, azonban bizonyos okok állandó félreértéseket szülnek. /4.) Hangsúlyozandó a túl nagy ambíció, amely hirtelen törik le] (133).

Thus, in Csáth's great "life-novel", the unreachable, immoderate ambition was on the one hand a saving grace that helped him heal his wounds and grow more conscious of his identity, and, on the other, a playful delirium that was possibly even more potent as a means of selfforgetfulness than morphine itself. Translating his musings and struggles remains even today a very difficult, yet deeply enriching task, while his life and work remains a unique "esthetics of intoxication", a monstrous text-body, half-awake, half- asleep, from the literal to literary, from fiction to autobiography.

\section{Works Cited}

Balogh, Tamás. 2004. “'Új regényen dolgozik Kosztolányi Dezső'. Az el nem keszült Mostoha cimü keletkezéstörténete ["Dezső Kosztolányi Works on a New Novel”: Genesis of the Unachieved Mother-in-Law]." Holmi. 11.4: 1401-1405.

Chmurski, Mateusz. 2013a. “'About the Rhythm of life'. Csáth's Diary: Theory and Practice of Text”. Danubius Noster. Forthcoming.

Chmurski, Mateusz. 2013b. “'Éreztem az életnek mint fictionak a szépséget' [I Felt as if my Life was a Fiction of Beauty]”. Évkönyv. Tanulmánygyüjtemény. Újvidéki Egyetem, Magyar Tannyelvü Tanitóképzö Kar Szabadka. Forthcoming.

Cooper, Thomas. 2011. "Envisioning or Effacing the Other: Different Approaches to Translation in the English and Hungarian Literary Traditions." Hungarian Studies. 25.1: 3-24. 
Chmurski, Mateusz. "From Autobiography to Fiction, or Translating Géza Csáth's Diary from Hungarian to French and to Polish." Hungarian Cultural Studies. e-Journal of the American Hungarian Educators Association, Volume 6 (2013): http://ahea.pitt.edu DOI: 10.5195/ahea.2013.113

Csáth, Géza. 1905. Orvosi Zseb-könyv [Medical Pocket Diary]. Országos Széchényi Könyvtár Kézirattára, Budapest, Acc. 457/4 [1]. . 1907. Wiener Medizinal Kalender [Viennese Medical Diary]. Országos Széchényi Könyvtár Kézirattára, Budapest, Acc. 457/4 [2]. . 1919a. Napló: 1897-1919 [Diary 1897-1919]. vol. 1-20. Petőfi Irodalmi Múzeum Kézirattára, Budapest, Acc. 2007/51/1. . 1919b. Noteszek [Notebooks]. vol. 1-18. Petőfi Irodalmi Múzeum Kézirattára, Budapest, Acc. 2007/51/2. . 1978. Egy elmebetegnö naplója [Diary of a Madwoman]. Budapest: Magvetö. . 1989. Napló: 1912-1913 [The Diary: 1912-1913]. Szekszárd: Babits Kiadó. . 1997. Fej a pohárban: napló és levelek, 1914-1916 [Head in a Cup: Diary and Letters 1914-1916]. Budapest: Magvető. . 1998. Le Silence noir. Nouvelles [The Dark Silence: Short Stories]. Trans. É. Brabant-Gerő \& E. Dauzat. Aix-en-Provence: Alinéa 1988. Repr. 2006. Le Jardin du mage. Talence: Arbre Vengeur. . 2000. The Diary: 1912-1913. Trans. P. Reich. Budapest: Angelusz \& Gold. . 2001. "Opowiadania"; "Dziennik 1912"; "Dziennik 1915 [Short Stories; The 1912 Diary; The 1913 Diary].” Trans. A. Górecka \& R. Żmuda-Trzebiatowsczi. Literatura na Świecie. 30.2-3: 5-89. . 2005a. Napló: 1897-1899 [Diary: 1897-1899]. Szabadka: Szabadegyetem. 2005b. Emlékirataim a nagy évről. Háborús visszaemlékezések és levelek. Szeged: Lazi. . 2006a. Napló: 1900-1902 [Diary: 1900-1902]. Szabadka: Szabadegyetem. . 2007a: Napló: 1903-1904 [Diary: 1903-1904].Szabadka: Szabadegyetem. . 2007b: Napló: 1905-1911 [Diary: 1905-1911].Szabadka: Szabadegyetem. . 2009: Dépendances. Trans. T. Loisel. Talence: Arbre Vengeur, 2009.

Farkas, Zoltán. 1990: “Csáth a lélekvesztőn [Csáth Losing his Soul].” Jelenkor. 42.1: 46-48. Földenyi F., László. 1991. "A halál tükreben élt élet. Csáth Géza naplójáról [A Life Lived in Death's Miror: On Géza Csáth's Diary].” Holmi. 2.4: 510-515.

Harkai Vass, Éva. 2010. “A Naplóíró Csáth Géza [The Diarist Géza Csáth].” Hungarológiai közlemények. 35.4.17-25.

Harmat, Pál. 1998. "Csáth Géza mint elmeorvos. Egy kórtörténet vázlata [The Psychiatrist Géza Csáth: Sketching a Case Story].” In Géza Csáth. Egy elmebeteg nö naplója: összegyüjtött elmeorvosi tanulmányok. Budapest : Magvető.

Hózsa, Éva. 1990. Csáth Géza. Napló 1912-1913 [Géza Csáth’s 1912-1913 Diary]. Üzenet. 20.6: 511-512.

Jókai, Mór. 1878. Görög tüz. Elbeszélések mindenféle igazhivők történetéböl [The Greek Fire]. 3 vols. Budapest: Athenaeum. Repr. 1897. Budapest: Révai Testvérek Kiadása.

Józan, Ildikó. 2007. "Irodalom és forditás [Literature and Translation]." In Szegedy-Maszák, Mihály - Veres, András. A magyar irodalom történetei, III: 1920-tól napjainkig. Budapest: Gondolat: 52-68.

Karinthy, Frigyes. 1919. "Csáth Géza.” Nyugat. 12.14-15.

Keresztúrszky, Ida, 1997. “Az örök áfium - Megalkotható-e Csáth Géza Ópium címü novellájának új olvasata? [The Eternal Opium, Or Is it Possible to Propose a New Reading of Géza Csáth’s Opium Short Story?]” Üzenet. 27.3-4.642-665. 
Chmurski, Mateusz. "From Autobiography to Fiction, or Translating Géza Csáth's Diary from Hungarian to French and to Polish." Hungarian Cultural Studies. e-Journal of the American Hungarian Educators Association, Volume 6 (2013): http://ahea.pitt.edu DOI: 10.5195/ahea.2013.113

Kosztolányi, Dezső. 1919. "Csáth Géza betegségéről és haláláról [On the Illness and Death of Géza Csáth].” Nyugat. 12.16-17.

Bogaert, Catherine \& Lejeune, Philippe. 2003. Un journal à soi. Histoire d'une pratique [A Diary for Oneself: History of a Practice]. Paris: Textuel. .2005. Le Journal intime. Histoire et anthologie [Personal Diaries: History and Anthology]. Paris: Textuel.

Mészöly, Miklós. 1980. "A játszótárs nélkül maradt értelem [A Mind Left without Company]." In id. Érintések: esszék. Budapest: Szépirodalmi Kiadó: 5-21.

Németh, Zoltán. 2001. “A férfivágy apoteózisa [The Male Desire’s Apotheosis].” Kalligram. 10.7-8: 61-70.

Schaeffer, Jean-Marie. 1999. Pourquoi la fiction? [Why Fiction ?] Paris: Seuil.

Sebestyén, Attila. 2007. "Agyvelö-akrobatika: Egy pszichofiziológiai müvészet- és kultúraelmélet keretei Csáth Gézánál [Brain Acrobatics, Or a Psychophysiological Frame to Géza Csáth's Art and Culture Ideas]." In Bónus, Tibor \& Kulcsár-Szabó, Zoltán \& Simon, Attila. Eds. Az olvasás rejtekútjai: müfajiság, kulturális emlékezet és medialitás a 20. századi magyar irodalomtudományban. Budapest: Ráció: 154-171.

Sebestyén, Attila. 2009. "Az élet a legjobb méreg (Drogmédiumok Csáth Gézánál) [Life’s the Best Poison: Drug-Mediums].” Alföld. 16.1: 98-109.

Szajbély, Mihály. 1997. "A naplóíró Csáth Géza [The Diarist Géza Csáth].” In Fej a pohárban: napló és levelek, 1914-1916. Budapest: Magvető: 308-319.

Szajbély, Mihály, Ed. 2004. A varázsló halála: in memoriam Csáth Géza [The Magician's Death: In memoriam Géza Csáth]. Budapest: Nap Kiadó.

Varga Z., Zoltán. 2011. "Az írói véna - Csáth Géza naplójegyzeteiről [The Writer’s Vein: On Géza Csáth’s Diary Notes].” TS. Earlier version: 2001. Üzenet. 31.1: 145-159.

Venuti, Lawrence. 1995. The Translator's Invisibility. New York: Routledge. 